\title{
Romans and Reducing Recidivism: Archaeology, social benefit, and working with offenders in Wales (Part 1)
}

\author{
Caroline Pudney \\ University of Chester, UK
}

Claims that public and community archaeology can help 'change lives' have recently come under criticism. Challenging these critiques, this article explores how archaeology can be socially beneficial in the rehabilitation of offenders. Using a case study from South Wales, the article demonstrates how a prison-based outreach project can offer an innovative trajectory for public archaeology, highlighting the links between archaeology and political agendas. The article challenges the concept of 'archaeologist-as-social-worker' and considers the successes and limitations of such an approach, including the challenges of measuring impact. Ultimately, it demonstrates that archaeology-based activities can provide positive life experiences for offenders but only through a successful partnership between heritage and offender management specialists, as part of a wider programme of support and intervention.

\section{Keywords}

Public archaeology, community archaeology, social benefit, prison, impact

\section{Introduction}

Inspired by recent discourse surrounding claims of community archaeology and social benefit archaeology (Carmen, 2011; Little \& Shackel, 2007; Simpson, 2009; Simpson \& Williams, 2008; Stottman, 2010; Zimmerman, et al., 2010), this paper tackles the longrunning debate of the social roles of public archaeology, particularly archaeologies with social purpose at their core. Through a discussion of a community archaeology project run by Cadw, the Welsh Government's Historic Environment Service, the article demonstrates a realistic role for archaeology in restorative practice linked to young offenders.

The article explores the outcomes of MORTARIA (Motivating Offender Rehabilitation Through Archaeological Recording, Investigation and Analysis) - a community archaeology project conducted by Cadw, in partnership with G4S Care and Justice Services and with support of National Museums Wales (Amgueddfa Cymru), between October 2012 and June 2014. The purpose of MORTARIA was to teach archaeology to offenders serving custodial sentences through interactive, hands-on workshops. The project consisted of two phases: a pilot project and a main stage of implementation. The pilot was initially delivered with the support from Amgueddfa Cymru and the Council for British Archaeology (CBA) but this evolved into a partnership with Cadw during the second phase of the project.

The project began during the author's CBA Community Archaeology Training Placement (CBA, 2015) and continued through subsequent employment with Cadw. The project was delivered at Her Majesty's Prison and Young Offenders' Institute, Parc (HMP $\&$ YOI Parc) and aimed to address social bias in access to heritage by taking heritage opportunities to new audiences, especially those experiencing social, economic and cultural deprivation. In turn this linked into the Welsh Government's agenda on tackling poverty, an aim of which is to help increase cultural and social experiences and raise 
aspirations within some of Wales' areas of multiple deprivation (Welsh Government, 2015).

MORTARIA, therefore, concerned opportunity provision: to help make heritage accessible to those who may not have previously experienced archaeology. A further aim was to explore potential social benefits of archaeology, specifically the ways in which participation in and engagement with archaeology can develop transferrable skills. It was not, therefore, explicitly concerned with altering attitudes to heritage or reducing recidivism, although they existed within this wider context. It was hoped that an effect of these projects would be to help reduce the increasing amount of heritage crime (specifically vandalism), which is often caused due to lack of education, engagement and therefore appreciation of historic sites and monuments (Grove, 2013; Kindred, 2011; Merrill, 2013; Wennberg, 2011; 2014).

\section{The wider context: Social benefit archaeology and public archaeology in Wales}

MORTARIA represents the first attempt to explicitly take archaeology into a prison environment within Wales as part of the rehabilitation process. However, there is precedent within the UK for archaeological projects to be conducted with prisons and offenders. For example, the Museum of London (MoL) have undertaken a range of projects in conjunction with HMP Wandsworth and the Josephine Butler Unit through which adults and young offenders produce creative artwork or poetry based around the collections and their experiences of London (MoL, n.d.). Similarly, the Shoreditch Community Excavation, also led by the MoL and partners, included young offenders within some of its wider activities with a view to help reduce reoffending rates in Hackney (Simpson, 2011).

These projects are exceptions, however. Not only do most community archaeology projects attempt to engage with inclusive community groups, not specific ones in terms of demographic or life experience, but some archaeology projects associated with offending have profitably focused on the archaeology and (dark) heritage of prisons (McAtackney, 2014) and internment camps (Mytum \& Carr, 2013; see also Cannon, 2014; O'Leary, 2015). Other work involving archaeology and offenders tends to centre on the use of forensic archaeology within the criminal justice system (Cox, 2001; Cox \& Bell, 1991; Hunter, et al., 1996; Hunter \& Cox, 2005). The project described here highlights the direct and tangible ways that the link between archaeology and criminality can be usefully developed.

Much of the recent debates pertaining to archaeology and the public good consider the broader economic, environmental and cultural benefits to communities and individuals (e.g. Beatrix, 2013; Bewley \& Maeer, 2014; Burtenshaw \& Gould, 2013; Little, 2012; Little \& Shackel, 2014; Rockman \& Flatman, 2012; Schadla-Hall, 2006). Specifically, the potential increase in social cohesion as a result of involvement in heritage projects has led archaeologists to explore how archaeology can help to build social capital (Little, 2007; 2012; Little \& Schackel 2014; Musil, 2003; Murzyn-Kupisz \& Działek, 2013). Some community archaeology projects have specifically sought to build communities and increase social capital (Derry \& Malloy, 2003; Dongoske, et al., 2000; Shackel, 2005; Simpson \& Williams, 2008). Through involvement in public or community archaeology, communities can become consolidated and the archaeologist can be perceived as facilitator and active citizen, contributing to society in a broader capacity.

Criticisms of social benefit archaeology suggest that claims made about the actual benefits may themselves need questioning (Isherwood, 2009; 2012; Sayer, 2014; Simpson, 2009). For example, Simpson (2009) notes that there is often a considerable 
difference in the espoused values and actual values of public and professionals involved in community archaeology projects, both at the start and as a result of a project. Isherwood (2012) and Sayer (2014) consider the ways in which political agendas affect public archaeology projects especially where politically loaded data is used to evaluate the successes of some. While archaeologies with social benefit are inherently linked to politics (Isherwood, 2009; Zimmerman, et al., 2010), the project discussed in this paper supports arguments made by Simpson and Williams (2008), by demonstrating that a realistic approach to the methods of measuring social benefits and the validity of the outcomes of community archaeology is needed, particularly when such close links to political agendas exist (Isherwood, 2009; 2012; Moshenska \& Dhanjal, 2012; Sayer, 2014). It is hoped that the following discussion can contribute to wider debates that centre on the ways in which archaeology and heritage are, and can be relevant to modern society. The project under review here should help to add an alternative perspective on archaeologies with specific social benefit.

The political context of public archaeology in Wales

Public archaeology in Wales has a long tradition going back at least to the early excavations of iconic sites such as Caerleon by Sir Mortimer Wheeler (Wheeler \& Wheeler, 1928) and V. E. Nash-Williams (1930; 1932), where local people were involved in excavations in a range of ways. Today, heritage organisations are active in their support of community archaeology (e.g. Clwyd-Powys Archaeological Trust n.d.; Dyfed Archaeological Trust n.d.; Glamorgan-Gwent Archaeological Trust Ltd. 2013; Gwynedd Archaeological Trust n.d.). Cadw also has a core role in the public archaeology of Wales, acting as statutory body for the protection of historic and ancient monuments with 129 monuments and sites in its care. Increasingly however, emphasis is being placed upon public archaeology creating a positive impact on and for society. For example, the archaeology departments at Welsh Universities also have a firm history in public archaeology in Wales, ${ }^{1}$ with the CAER Project (Ancarno, et al., 2016), specifically targeting the local population - a 'Communities First' area (i.e. an area of multiple deprivation) (Welsh Government, 2014a).

This type of social benefit archaeology has been magnified by the current political situation in Wales. In Wales, under a devolved labour government, there exists a major drive to address poverty -economic, social, cultural and aspirational. The Welsh Government's Tackling Poverty Action Plan (Welsh Government, 2012), has led to considerable pressure being placed upon all Welsh Government funded organisations, including heritage and arts bodies, to address major government agendas, help demonstrate how portfolios are achieving targets, and justify the expenditure of public funds (Cadw 2013; Welsh Government, 2013a). In order to gain funding for valuable community engagement projects and achieve some of the wider aims of heritage organisations, projects have to match government-led funding criteria in the form of tackling poverty. This is not however, a bad thing because it has resulted in the ability to achieve both benefits for heritage and help to create social capital.

Cadw's Community Archaeology Framework (Welsh Government, 2013b), which is explicitly linked to wider Cadw and Welsh Government policies and frameworks ${ }^{2}$, emphasises the role of community archaeology in Wales beyond solely providing benefits for the historic environment. These priorities were furthered in 2014 when Baroness Andrews was commissioned by the Welsh Government to provide a report entitled Harnessing the power of the arts, culture and heritage to promote social justice in Wales (Welsh Government, 2014b). Together with an earlier report (Smith, 2013), it sought to 
identify possible methods in which cultural and heritage bodies can work more closely together to broaden access to, appreciation of and participation in, culture in ways that contribute to reducing poverty.

It was within this political, social and economic environment that the MORTARIA project was developed and delivered

\section{Project environment}

HMP \& YOI Parc is located near Bridgend, South Wales. The facility is currently the only privately run prison in Wales and is managed by G4S Care \& Justice Services on behalf of the National Offender Management Services (NOMS). The prison accommodates over one and a half thousand convicted male adult prisoners (aged 18 years and above) and also houses remand and convicted young people (aged 15-17 years). The majority of adult prisoners are serving sentences between 2 and 10 years in length (Her Majesty's Inspectorate of Prisons, 2014). The main adult prison population at the time of the MORTARIA project mostly consisted of white males, with Asian, Black and mixed ethnicities forming the next largest groupings (Independent Monitoring Boards, 2012). This continues to be largely the same, even since the expansion of the prison in 2014, which took the operational capacity up to 1743 prisoners and 64 young people (Independent Monitoring Boards, 2014; 2015).

The philosophy of Parc is to rehabilitate offenders and equip them to re-integrate into society upon release, following a wider policy of restorative justice. In order to achieve this prison conditions are normalised as far as possible and reflect life in the outside community (HMP \& YOI Parc, 2014). On average, around $80 \%$ of the adult prison population are in employment and/or education within the prison (Independent Monitoring Board, 2015). The participants of the MORTARIA project were the GCSE history class and therefore already entrenched within the education department of the prison.

HMP \& YOI Parc adopts a multi-disciplinary approach to working with learners and education is available in basic numeracy and literacy, to vocational training, to distance learning degree-level study (HMP \& YOI Parc, 2014). This is in line with wider practice across UK prisons. In general terms educational attainment among offenders, both adult and young people, tends to be relatively low and the majority of inmates have little or no employable skills. Studies suggest that offenders are often school dropouts and many also have specific learning difficulties (Vacca, 2004; Wilson \& Reuss, 2000). Effective prison-based education programmes are therefore established with the aim of helping to develop academic achievements, social skills and the artistic development of individual offenders (Clements, 2004; Vacca, 2004; Warner, 2002). Programmes also help offenders to find techniques and strategies that assist them to cope with emotions (Gordon, 2000; Vacca 2004; Wilson \& Reuss, 2000). Education provisions therefore aim to provide academic, vocational and social education. By offering a wide range of learning opportunities, it is thought that more can be attracted into education and that the needs of the whole person can be addressed (Bayliss, 2003; Warner, 2002). Such an approach to education can therefore create opportunities for archaeologists and other heritage specialists to help increase the variety of learning opportunities.

\section{Working in a secure environment}

Unsurprisingly, security was a key factor in the prison environment. Beyond the obvious control of things (and people), moving in and out of the prison on a daily basis, the safety of staff, visitors and residents was paramount. The strict rules concerning security meant 
that much of the equipment used in the projects required special, high-level clearance. There are restrictions on glass objects entering the prison. Similarly, weapons are not permitted within the prison and tools can only be permitted under strict security measures. This would have an impact on the items we sought to take in for the purpose of the project, especially relating to both real and replica metal and stone artefacts. USB or data storage devices were also not permitted. Any digital materials therefore had to be burnt to read-only CD or DVD prior to entry. Everything had to be itemised and signed off individually, even down to basic stationary supplies.

Residents do not have access to the internet, although an intranet is available to some, this has knock-on effects to the projects and activities conducted within the prison. A library is run by Bridgend County Library Services and access to books is available to all inmates. As part of the project, a quantity of archaeology books was donated to the library. Library borrowing records indicated that many of the books were popular, especially the Cadw site-specific guidebooks, suggesting that inmates had an interest in reading about specific monuments. The records also demonstrate that the books were not solely popular among the participants in the project, thus extending the reach of the project beyond the immediate participants.

Despite the security issues we were able to work with G4S staff at Parc to create an effective project within the security parameters of the prison. Most of the authentic and replica artefacts we utilised were permitted through security, although even once items had been cleared in advance everything had to be thoroughly searched by security staff before physically being taken inside. They required counting, a process that was then repeated on leaving the prison to ensure no items were missing. In addition, those involved in the project who did not work for G4S had to undergo security checks. Despite this, the fact that we were permitted to and perhaps more importantly, trusted to bring such items into the prison was to the testament of the staff at HMP\&YOI Parc and their commitment to offering a range of experiences in their attempts to help reduce recidivism.

\section{Participants}

The project participants were aged between 19 and 65 years old, c.85\% of which originated from a white, British ethnic background, reflecting the general demographic of the prison population. As already mentioned, the group constituted the GCSE history class. Involving a group who already expressed a desire to be involved in the project seemed optimal for the pilot project. This also proved to be the most successful option from a logistical point of view since it provided the least operational disturbance. It also meant that participants were categorised at an appropriate risk level for inclusion within such a project, although some special dispensations were made for some activities.

Personal conversations with participants, where information was volunteered freely, indicated that socioeconomic, family and childhood dynamics (current, recently past or even more distant), had contributed to their offending behaviour. Some of the participants were involved in violent crimes, serving substantial sentences while others were acquisitive offenders (mostly drug related). A large proportion of these were repeat offenders. In general, social background and life-course often plays a significant role in an offender entering the crime-cycle (Backman, et al., 2014) and it has been commonly argued that offending behaviour can be linked to those from low socio-economic backgrounds (Ellis \& MacDonald, 2001; Fergusson, et al., 2004; Greg, et al., 2005). The majority of participants derived from the South Wales area, especially the Valleys, Newport, Cardiff, Swansea, Neath, Port Talbot and Llanelli, thus reflecting the wider 
demographic of the prison population (Wales Reducing Reoffending Strategy 2014 2016: 12). Higher crime rates across these areas have been argued to correlate with high unemployment, low educational attainment and skills shortages, particularly amongst men and young people (Wales Reducing Reoffending Strategy 2014 - 2016: 12). This then perpetuates a cycle of disadvantage whereby large numbers of children grow up in workless households and experience the effects of deprivation. Familial situations, behavioural difficulties and mental health also often play significant roles in the lives of offenders (Fazel \& Danesh, 2002; Fazel \& Lubbe, 2005; Fazel, et al., 2008). For many, these are also linked issues of substance abuse (Fazel, et al., 2006). This was echoed in the stories and anecdotes recounted by project participants during the course.

\section{MORTARIA (Motivating Offender Rehabilitation through Archaeological Recording, Investigation and Analysis).}

\section{The Pilot phase}

The initial phase of the MORTARIA project took place in 2012. This consisted of day long workshops on Roman Wales held over the course of 12 weeks. An example lesson plan can be found in Appendix 1. Artefacts (real and replica) were brought into the prison with the help of Amgeuddfa Cymru (National Museum Wales, Cardiff and the National Roman Legion Museum, Caerleon). Sessions were mostly delivered by the author. Topics were designed to be discursive and participants engaged in a mixture of numeracy, literacy, oral, aural and creative activities. The course encompassed themes of landscape, materiality, death and commemoration, religion and ritual, consumption, identity and so on, with a mixture of didactic and more experiential learning strategies employed. Archaeological methods and heritage management were also included. For example, a session on Roman rubbish involved the categorisation of objects by material, and then by function; the recording of artefacts by closely observing them, writing descriptions, measuring, and weighing them (using artefact record cards), much as would be done in any post-excavation environment. We then discussed issues of taphonomy and formation processes, and drew wider conclusions concerning diet and rubbish disposal. This then led to a discussion of participants own diet and rubbish disposal methods and ultimately, our impact on the world. The following week, this was followed up with a practical cooking session, preparing a Roman-style feast to share with prison staff, including the Governor.

\section{Main Phase}

The second phase of the project took place in 2013-14, with 12 new participants. Using the same format as the workshops in the pilot and also involving the GCSE history group the course covered British archaeology chronologically. The expansion of the scope from Wales to Britain was a result of feedback from participants during the Pilot Phase, who expressed that they would have liked to gain a broader sense of chronological developments across the British Isles. Beginning with the Palaeolithic, each week the workshop's topic moved forwards through time encompassing many of the same themes and methods as the pilot phase and much the same as the content of an introductory undergraduate course might do (see Appendix 2). A greater range of speakers was introduced during the main phase, and incorporated other specialists from Amgeuddfa Cymru and Cadw.

The second phase was also mapped on to existing Agored Cymru Level 1 Award and Certificate accredited course 'Window on Wales' (Agored Cymru, 2012). In order to 
improve upon the pilot phase, accreditation was considered to be a positive addition. As a result of time constraints, it was not possible to gain accreditation for the course itself however, it was possible to tailor it to fit the requirements of the Agored Cymru accreditation. Handbooks were designed to assist in this and participants kept a portfolio of their work. ${ }^{3}$

\section{Both phases}

Each delivery phase included a cookery session in which participants cooked a meal using Roman or medieval recipes. The participants particularly appreciated this aspect of the course, both for the different types of meat they could enjoy (versus the food served in the canteen), but also because they were trusted to work in a high-risk environment of the training kitchen. ${ }^{4}$ The training kitchen is used for catering courses however, only those deemed by the prison and NOMS at an appropriate risk level are able to enrol upon such courses. The MORTARIA participants were regarded as privileged to participate in this activity since some of them may not have been ordinarily deemed the appropriate risk level and this trust appeared to boost morale within the group.

The pilot and second phase contained at least two art-based classes. The art department within the education block at Parc housed several potters' wheels and a professional pottery kiln. Usually these were used for those studying art GCSE, A-Level or equivalent qualifications. Using modern modelling clays, Roman pottery forms were attempted by some participants while others opted for more of a prehistoric, coil technology. One participant even decided to make small figurines in the form of his wife and children, along similar lines to those of the household or family spirits found across the Roman world.

The cookery and art sessions aimed to promote an alternative, experiential learning style, integrating the more formal methods of comprehension with creative responses to new-found knowledge and understanding. Oral communication and reasoning was enhanced through classroom debates (often quite heated and very competitive), and group presentations. Similarly, activities requiring literacy skills were included, such as the poster presentation at the end of the course that took place during their 'graduation' ceremony. The presentation consisted of themed posters, the topics for which were chosen and the posters designed by participants based upon what they had learnt and achieved.

Both phases concluded with a high-profile event in which the governor of the prison, the Director of Cadw, and participants' peers shared in presentations of the achievements.

\section{Evaluation and Impact}

Measuring impact is often the complex part of many outreach or engagement projects. Evaluation is critical not only in justifying the motivations for the project but also the financial support and proving the successes (or lack thereof) of any project. This is especially evident in funding applications, for example in the Heritage Lottery Fund's criteria and guidance (HLF, 2012). Evaluation is not solely needed for ticking the boxes of various funding bodies. More importantly, it is fundamental for reflecting on the effectiveness of a project. When working with any group there is always a risk that an intervention may cause harm rather than good. This risk is increased when dealing with vulnerable groups (Feinstein, 2005). Evaluation helps us to continue to monitor this risk.

It is easy enough to count the number of participants in a project. This 'bums-onseats' quantitative approach is relatively simple data to collect and often used as an 
indicator of success. Figures can be broken down into numbers of individuals engaged at different levels (e.g. those involved in hands-on activities or spectators at an event. It is also simple to quantify individuals who have gained qualification or accreditation through a project. Similarly, the economic impact of a project on a specific area can be calculated (Bewley \& Maeer, 2014). Measuring the more intangible outcomes, such as increases in self-esteem, behavioural or attitude change is however, more problematic and often requires a more reflexive approach (Simpson \& Williams, 2008).

The impact of MORTARIA Project was recorded through standard prison evaluation questionnaires and the author's project diary. Project portfolios were also available for the main phase, whether submitted for qualification or not. Concept maps were also employed in some situations. As such the main evaluation methods utilised were qualitative through observations and conversations, with basic quantitative data collection where available. Based on the aims of the project the impact was evaluated under four main areas: access to heritage (the 'bums-on-seats' approach), learning, and behavioural changes.

\section{Access to heritage}

The project did indeed succeed in widening access to heritage. Over the course of both of the MORTARIA deliveries, there were a total of 30 participants. On most days, there was at least one absence due to the fluid nature of the prison environment. Over the duration of the project approximately $70 \%$ of participants completed the full 12 weeks of each delivery phase. The remaining 30\% was due to a combination of some men transferring to paid employment within the prison, for which they were on a waiting list of applications prior to the start of the course. Others were simply transferred to an alternative custodial facility. They were then often replaced with a new participant, who in turn would also only be able to engage with part of the course. This could happen to any prisoner, at any time. Prior warning would not be provided for security reasons and it was therefore out of the hands of the education staff at the prison. This had an impact on the design of each session, which needed to be able to act as a stand-alone session and not be wholly dependent on topics covered previously. Only one individual opted to leave the project due to low interest, although it should be noted this was also related to with difficulties in balancing his medication. One participant on each phase of delivery was released part-way through the course, having served their minimum sentences.

Of the 12 men who participated in the main phase, half were suggested to be put forward for the Agored Cymru accreditation. Their portfolios have been monitored by the author and were returned to the prison so that they could be sent to the awarding body. Confirmation of their success unfortunately remains forthcoming. This delay is a direct impact of a change of personnel involved in the project. The degree to which any qualification gained during the MORTARIA project may assist in later employment, education or training is therefore not possible to evidence at this stage.

\section{Learning}

Knowledge attainment was gauged through the simple use of concept maps, a diagrammatic tool through which knowledge can be organized and structured (Jackson \& Trochim, 2002; Markham, et al., 1994; Wheeldon \& Faubert, 2009). For example, concept maps were drawn by each participant at the start of the course and at the end. Over the course of the first delivery (pilot project), the rather bare and limited maps with information they knew about the Romans and Roman Britain came to be complex maps filled with information about the make-up of the Roman military, the ways in which the 
dead were buried, details of specific archaeological sites and how archaeologists undertake their inquiries.

"The archaeology course was very interesting with a lot of different aspects to it. The lessons themselves were not too intense which promoted the students to learn easier and pick up more information about things like the Roman military (formations, structure and hierarchy of legions) etc."

\section{Participant A}

The ability to measure longer-term knowledge retention would be beneficial, and is worth following up, although the logistical issues associated with this may make it unfeasible. This is largely due to the difficulties in tracking the longer-term whereabouts of each participant whether they may have been transferred to an alternative facility or released.

\section{Behavioural change}

The participants' prior interest in history helped to engage what could have been a potentially tougher audience. Many of the men knew of historic sites or monuments near their homes. None of the participants had any direct experience of the practice of archaeology beyond what they had watched on television. All participants learnt about historic sites on their doorstep which they had not previously been aware. They were also then able to put them in their wider historic and social context. Approximately two thirds of participants said that they would actively seek out a heritage site to visit on their release while in reality, barriers such as cost of travel and entry fees would likely materialise (Rahim \& Mavra, 2009).

The evaluation of the emotional and behavioural impact of the project could have been more effective. Long-term attitude or behavioural change was difficult to establish. The immediate increases or decreases in enthusiasm of the participants was clear to the observer. Some days the atmosphere was more sombre yet on others it was fully animated, mirroring the changeable nature of the prison environment. On many days it was clear to see that the workshop itself altered the atmosphere in the class.

Despite the difficulties in the monitoring and recording of behavioural or attitude change, social sciences are increasingly developing new approaches to measure such impacts. In this particular instance, a longer planning period might have allowed for better partnerships with prison psychologists. This way full psychological evaluation could have been conducted before, during and after each project delivery phase. The greatest issue with this would be the risk that the participants felt that they were being monitored and assessed in some way, which in turn, would have a dramatic effect on both their behaviour and the atmosphere in the workshop. If this was incorporated in some way we would likely have stronger evidence for any behavioural or attitude change of participants and/or those delivering the project. Such time constraints are, all too often impact on project organisation and success (Simpson, 2009), when funding follows annual cycles, especially when budgets are only confirmed well into that very financial year and then completion and reporting also needs to take place within the same annual cycle.

It is often the things that cannot be measured that demonstrate the biggest impact. The awe and privilege felt by many of the participants when they were able to hold Roman objects recently excavated from Priory Field, Caerleon (Guest \& Gardner, forthcoming), was something that I, as project lead, will never forget. The objects had 
been excavated during 2010 and had recently gone through the conservation process at Cardiff University's Department of Archaeology and Conservation ${ }^{5}$. They were yet to be seen by the general public. It was clear that such a privilege was genuinely appreciated by the participants.

Similarly, the trust instilled in the participants to be allowed to use the training kitchen, the pottery and art equipment was something that, in an environment where trust is often a contentious issue, did not go unnoticed. Participants were clearly gratified by the trust given to them and the responses to this were clear. Their behaviour was generally very good within the workshops. No incidents were recorded during the workshops of both MORTARIA deliveries. The respect offered to both myself and prison staff involved in the project was evident. A mutual, two-way relationship of trust and respect existed.

\section{Looking backwards and moving forwards}

The MORTARIA Project was successful in a variety of ways. Further successes relating to the impact upon those involved in the project should not however, be over-stated but instead viewed with realism.

The participants appeared to enjoy themselves and expanded their knowledge of their local heritage. It provided new experiences and on occasion forced them to step beyond their immediate social circles to interact with people from often very different backgrounds. The topics covered in the workshops challenged participants and those delivering the projects to consider new or alternative perspectives on both the modern and ancient worlds. Archaeology provided an exciting hook to engagement. Feedback from the prison indicated that MORTARIA delivered enriched experiences for those involved and provided a range of experiences in a way that other, more traditional academic disciplines would not ordinarily allow. It provided a particular level of access to heritage and archaeology, potentially opening new avenues of interest.

The resultant effect on recidivism, including heritage crime is, at this stage, unknown and any direct link would be extremely hard to evidence. Benefits for archaeology and heritage can, however, be found in the lessons learnt from reaching out to communities such as that at HMP \& YOI Parc. In this sense these projects were a good investment, since the education and exchange of was a two-way process that led '...to mutual respect and a recognition of different perspectives.' (Pardoe, 1992: 138).

Capacity building was perhaps a key benefit for heritage. The projects assisted in forging strong links between Cadw, other heritage organisations and HMP \& YOI Parc. All of which are now leading on to further partnership projects that build upon the achievements to date, thus helping to build capacity both within and beyond the heritage sector. The Welsh Archaeological Trusts and Amgueddfa Cymru continue to work with 'hard-to-reach' groups. Cadw are now involved in a HLF project working with young people from disadvantaged backgrounds and 20th century remains (Cadw, 2014). Cadw continues to have a relationship with Parc, with a view to including heritage construction techniques such as lime-mortaring, within existing vocational training courses (pers. comm. Jon Berry, 14 September 2015).

\section{Moving forwards}

With many projects those involved are able to witness first-hand behavioural changes or the development of soft skills, yet this is only the immediate, short-term impact. As with many evaluations of social benefit within the heritage sector, responses and feedback are collected during, immediately or shortly after participation or involvement in heritage- 
based activities. Any longer-term impact is therefore not accounted for. This is unfortunate since it is in the longer-term where the ideal impact may materialise - once an offender has served their sentence and is back in the community, integrating with society, culture and entering into an often very daunting new phase of their life. In order to monitor this more effectively, the involvement of prison psychologists would have been required and also the co-operation and buy-in of the probation services, since the prison service will not have much, if any, involvement in the lives of the offenders once they leave the institution. While the project explored this possibility, the dynamic and changeable environment of the prison meant that such assessments would be very difficult to organise. As such it was not possible on this occasion, largely due to the time constraints on the project, but should be something put in place for any similar, future project.

\section{Conclusion}

Social benefit public archaeology projects can help build social capital, especially involving vulnerable groups such as adults or young people involved in offending behaviour. However, they may not do this in the ways we expect and we should not be surprised if participants' values of heritage do not drastically change as a result of engagement with archaeology. Projects need to be specifically tailored to each individual situation, the needs and the environment within which it is situated.

There is a clear desire to provide as many different and dynamic opportunities for offenders within the penal system. As previously argued by Tully (2007: 171), collaboration on community archaeology projects is paramount. Without the support of other specialists such as the staff at HMP \& YOI Parc, the projects illustrated here would indeed have run the risk of promoting the 'archaeologist-as-social worker' perception. Instead, in association with a much wider programme of activities and interventions provided by Parc, projects like the MORTARIA are able to play a worthwhile part in strategies to reduce recidivism, no matter how small that part is. The challenge for this author (and others), is to develop a model which could effectively be implemented at a range of offender management institutions. The possibilities for a translational (Zimmerman, et al., 2010) public archaeology is discussed in more depth in Part 2 of this article (Pudney, 2016). For now though, MORTARIA has provided a starting point from which there is much potential to explore the role of archaeology within progressive approaches to tailoring educational outreaches towards identified groups who have been deprived of access to and education about heritage, and perhaps also reducing recidivism.

\section{Acknowledgements}

The projects focused on in this article would not have been possible without the Welsh Government, Cadw, Amgueddfa Cymru, Her Majesty's Prison and Young Offenders Institution, Parc, G4S and the Ministry of Justice. Particular thanks go to Laurence Bater and the team at HMP Parc, Jon Berry and Polly Groom (Cadw) and Mark Lewis and Mark Redknapp (Amgueddfa Cymru). Faye Sayer and Howard Williams were kind enough to read previous drafts of the article and provide comment. Thanks also to the editors' and anonymous reviewers' constructive and positive comments. Any mistakes, inaccuracies or oversights remain the author's own.

\section{Note on contributor}

Caroline Pudney is a Lecturer in Archaeology at the University of Chester. Her main research focus is on Iron Age and Roman Britain, particularly the agency of objects. As a 
former community archaeologist, Caroline also has a specific interest in debates surrounding public archaeology.

Correspondence to: Department of History \& Archaeology, University of Chester, Parkgate Road, Chester, CH1 4BJ. Email: c.pudney@chester.ac.uk

\section{Bibliography}

Agored Cymru. 2012. Qualification Guide: Award in Window on Wales and Certificate in Window on Wales. Available at:

http://www.agored.cymru/GetFileQuartz.aspx?fileid=5430441\&qualid=126577 Accessed $16 / 11 / 2015$

Ancarno, C., Davies, O. and Wyatt, D. 2016. Forging communities: the Caerau and Ely Rediscovering Heritage Project and the dynamics of co-production. In D. O'Brien and P. Matthews eds. After Urban Regeneration. Communities, policy and place. Policy Press: Bristol, 113-130.

Backman, O., Estrada, F., Nilsson, A., and Shannon, D. 2014. The Life Course of Young Male and Female Offenders. Stability or Change between Different Birth Cohorts? The British Journal of Criminology 54(3), 393-410

Bayliss, P. 2003. Learning behind bars: time to liberate prison education. Studies in the Education of Adults 35(2), 157-172.

Beatrix, A. 2013. Making it Work: Using Archaeology to Build Job Skills for Careers Other Than Archaeology. Public Archaeology 12(2), 79-100

Bewley, R. and Maeer, G. 2014. Heritage and Economy: Perspectives from Recent Heritage Lottery Fund Research. Public Archaeology 13 (1-3), 240-9.

Burtenshaw, P and Gould, P. 2013 Archaeology and Econonomic Development. Public Archaeology 13(1-3), 3-9.

Cadw 2013. Changing Cultures Initiative Aims to Change Lives. 7/2/2013. Available at: http://cadw.gov.wales/about/news/archive/7023202/?lang=en. Copyright Cadw, Welsh Government 2015. Accessed 10/11/15

Cadw 2014. A step closer to uncovering Wales's 'unloved heritage'. News. 3/7/2014. (C) 2015 Cadw, Welsh Government. http://cadw.gov.wales/about/news/a-step-closer-to-uncoveringwales-unloved-heritage/?lang=en Accessed 16/11/2015.

Cannon, J. (ed.) 2014. Unlocking the Past: Her Majesty's Prison Nothallerton. Research News 21. English Heritage, 35-37.

Carmen, J. 2011. Stories We Tell: Myths at the Heart of 'Community Archaeology'. Archaeologies $7(3), 490-501$ 
Clements, P. 2004. The Rehabilitative Role of Arts Education in Prison: Accommodation or Enlightenment?. International Journal of Art \& Design Education, 23, 169-178.

Council for British Archaeology. 2015. Workplace Learning for Community Archaeologists: A Skills for the Future project, 2011 - 2015. CBA Research Bulletin 5.

Cox, M., \& Bell, L. 1999. Recovery of human skeletal elements from a recent UK murder inquiry: preservational signatures. Journal of Forensic Science, 44(5), 945-950

Cox, M. 2001. Forensic archaeology in the UK. Archaeologies of the contemporary past, Routledge, London and New York, 145-57

Clwyd-Powys Archaeological Trust n.d. Outreach Activities.

http://www.cpat.org.uk/outreach/outreach.htm Accessed: 13/11/2015

Derry, L. and Malloy, M. (eds.) 2003. Archaeologists and Local Communities: Partners in Exploring the Past. Washington DC: Society for American Archaeology.

Dongoske, K., Aldenerrfer, M., and Doehner, K. (eds.). 2000. Working Together: Native Americans and Archaeologists. Washington DC: Society for American Archaeology.

Dyfed Archaeological Trust n.d. Community Archaeology.

http://www.dyfedarchaeology.org.uk/heritagemanagement/communityarch.htm Accessed: $13 / 11 / 2015$

Ellis, L., and McDonald, J. N. 2001. Crime, delinquency, and social status: A reconsideration journal. Journal of Offender Rehabilitation 32(3)123-52.

Fazel, S. and Danesh, J. 2002. Serious mental disorder in 23000 prisoners: a systematic review of 62 surveys. The Lancet 359(9306), p545-550

Fazel, S., and Lubbe, S. 2005. Prevalence and characteristics of mental disorders in jails and prisons. Current Opinion in Psychiatry 18(5), 550-554.

Fazel, S., Bains, P., and Doll, H. 2006. Substance abuse and dependence in prisoners: a systematic review. Addiction 101(2), 181-191.

Fazel, S., Xenitidis, K., and Powell, J. 2008. The prevalence of intellectual disabilities among 12000 prisoners - A systematic review. International Journal of Law and Psychiatry 31(4), 369-373.

Feinstein, S. (2005). Another look at scared straight. Journal of Correctional Education, 56(1), 4044.

Fergusson, D., Swain-Campbell, N., and Horwood, J. 2004. How does childhood economic disadvantage lead to crime? Journal of Child Psychology and Psychiatry, 45(5):956-966

Gordon, R. 2000. Prison Education: One Inmate's Experience. In D. Wilson and A. Reuss, (eds.) Prison(Er) Education: Stories of Change and Transformation. Winchester: Waterside Press. 172182. 
Greg, G., Kalil, A., Mayer, S. E., Tepper, R., and Payne, M. R. 2005. The apple does not fall far from the tree. In S.Bowles, H. Gintis, and M. Osbome (eds.) Unequal Chances: Family Background and Economic Success. Princeton, NJ: Princeton University Press.

Grove, L. 2013. Heritocide? Defining and Exploring Heritage Crime. Public Archaeology 12(4), 242-254.

The Glamorgan-Gwent Archaeological Trust Ltd. 2013. Community Archaeology. http://www.ggat.org.uk/engagement/com arch.html Accessed 13/11/2015.

Guest, P. and Gardner, A. Forthcoming. Priory Field: Excavating a Legionary Store Building.

Gwynedd Archaeological Trust. n.d. Community Engagement. http://www.heneb.co.uk/newhmcommunityengagement.html Accessed 13/11/2015

Her Majesty's Inspectorate of Prisons 2014. Report on an unannounced inspection of HMP/YOI Parc by HM Chief Inspector of Prisons, $9^{\text {th }}-1^{\text {th }}$ July 2013. Crown Copyright.

Heritage Lottery Fund. 2012. Evaluation Good-practice Guidance, October 2012. Available at: http://www.hlf.org.uk/file/10877/download?token=azdTKprFZSamoXpAUtq2t9MtagES1wB30 HqKDTjbj94 Accessed 10/11/2015

HMP \& YOI Parc. 2014. Welcome to HMP \& YOI Parc. http://www.hmpparc.co.uk. Date Accessed: $09 / 11 / 2015$.

Hunter, J., Roberts, C. A., \& Martin, A. 1996. Studies in crime: an introduction to forensic archaeology. Psychology Press.

Hunter, J., \& Cox, M. 2005. Forensic archaeology: advances in theory and practice. Psychology Press.

Independent Monitoring Boards 2012. Annual Report. HMP \& YOI Parc, March 2011 - February 2012.

Independent Monitoring Boards 2014. Annual Report. HMP \& YOI Parc, March 2013 - February 2014. Monitoring Fairness and Respect for People in Custody

Independent Monitoring Boards 2015. Annual Report. HMP \& YOI Parc, March 2014 - February 2015. Monitoring Fairness and Respect for People in Custody

Isherwood, I. 2009. Community Archaeology. A study of the conceptual, political and practical issues surrounding community archaeology in the United Kingdom today. University of Manchester: Unpublished PhD Thesis

Isherwood, R. 2012. Community Archaeology: Conceptual and Political Issues. In D. Moshenska, and S. Dhanjal (eds.) Commnity Archaeology: Themes, Methods and Practices. Oxford: Oxbow, 617.

Jackson, K., and Trochim, W. (2002). Concept mapping as an alternative approach for the analysis of open-ended survey responses. Organizational Research Methods, 5(4), 307-336. 
Kindred, B. 2011. Current Initiatives to Address Heritage Crime in the UK. Journal of Architectural Conservation 17(2), 43-58.

Little, B. J. 2007. Archaeology and Civic Engagement. In B. J. Little and P. A. Shackel (eds.) Archaeology As a Tool of Civic Engagement. New York: Alatamira Press, 1-22.

Little, B. J. 2012. Public Benefits of Public Archaeology. In, R. Skeates, C. McDavid and J. Carmen (eds.) The Oxford Handbook of Archaeology. Oxford: Oxford University Press, 395-413.

Little, B. J. and Shackel, P. A. (eds.) 2007. Archaeology As a Tool of Civic Engagement. New York: Alatamira Press

Little, B. J. and Shackel, P. A. 2014. Archaeology, Heritage and Civic Engagement. Walnut Creek CA: Left Coast Press

Markham, K. M., Mintzes, J. J. and Jones, M. G. (1994), The concept map as a research and evaluation tool: Further evidence of validity. Journal of Research in Science Teaching, 31(1), 91101. (doi: 10.1002/tea.3660310109)

McAtackney, L. 2014. An Archaeology of the Troubles: The Dark Heritage of Long Kesh/Maze Prison. Oxford: Oxford University Press.

Merrill, S. O. C. 2013. Graffiti at Heritage Places: Vandalism as Cultural Significance or Conservation Sacrilege? Time and Mind: The Journal of Archaeology, Consciousness and Culture $4(1), 59-75$

Moshenska, D and Dhanjal, S. 2012. Introduction: Thinking About, Talking About and Doing Community Archaeology. In D. Moshenska, and S. Dhanjal (eds.) Commnity Archaeology: Themes, Methods and Practices. Oxford: Oxbow. 1-5.

Museum of London (n.d.) Past Inclusion Projects.

http://www.museumoflondon.org.uk/get-involved/collaborative-projects/inclusion-pastprojects/Accessed on 10/02/2015

Musil, C. McT. 2003. Educating for Citizenship. Peer Review 5(3), 4-8.

Murzyn-Kupisz, M. and Działek, J. 2013. Cultural heritage in building and enhancing social capital. Journal of Cultural Heritage Management and Sustainable Development 3(1) , 35-54

Mytum, H. and Carr, G. (eds.) 2013. Prisoners of War. Archaeology, Memory, and Heritage of 19th- and 20th-Century Mass Internment. New York: Springer.

Nash-Williams, V. E. 1930. The Roman Legionary Fortress at Caerleon in Monmouthshire. Report on the Excavations Carried out in Jenkins' Field, 1926. Cardiff: University of Wales Press.

Nash-Williams, V. E. 1932. The Roman Legionary Fortress at Caerleon in Monmouthshire. Report on the excavations carried out in the Prysg Field 1927-9. Cardiff: National Museum of Wales and the University of Wales. 
O'Leary, A. 2015. 'Archaeological dig reveals secrets of gruelling Salford Prison'. Manchester Evening News. 8 ${ }^{\text {th }}$ March 2015.

http://www.manchestereveningnews.co.uk/news/greater-manchester-news/archaeologicaldig-reveals-secrets-gruelling-8794104. Accessed on 09/11/2015.

Pardoe, C. 1992 Archers of radii, corridors of power: reflections on current archaeological practice. In, B. Atwood, J. Arnold (eds) Power, knowledge and Aborigines. La Trobe University Press, Melbourne, 132-141.

Pudney, C. forthcoming Translational Public Archaeology? Archaeology, social benefit, and working with offenders in Wales. Part 2 Public Archaeology

Rahim, N., and Mavra, N. 2009. Barriers to Engagement in Heritage by Currently UnderRepresented Groups. An Inclusion Report to the National Audit Office. Inclusion Research and Consultancy.

https://www.nao.org.uk/wp-content/uploads/2009/07/0809881_barriers.pdf. Accessed $14 / 04 / 2013$.

Rockman, M. and Flatman, J. 2012. Archaeology in Society. Its Relevance in the Modern World. New York: Springer

Sayer, F. 2014. Politics and the Development of Community Archaeology in the UK. The Historic Environment 5 (1), 55-73.

Schadla-Hall, T. 2006. Public Archaeology in the Twenty-First Century. In R. Layton, S. Shennan and P. Stone (eds.) A Future for Archaeology: The Past in the Present. Left Coast Press. 75-82.

Shackel, P. 2005. Memory, Civic Engagement and the Public Meaning of Archaeological Heritage. SAA Archaeological Record 5(2), 24-27

Simpson, F. 2009. The Values of Community Archaeology: A Comparative Assessment. University of Exeter: Unpublished PhD Thesis.

Simpson, F. 2011. Shoreditch Park Community Excavation: A case study. In S. Dhanjal \& G. Moshenska (eds) Community archaeology: Themes, methods and practices. Oxford: Oxbow Books Limited, 115-19.

Simpson, F. and Williams, H. 2008. Evaluating Community Archaeology in the UK. Public Archaeology 7(2), 69-90

Smith, D. 2013 An independent report for the Welsh Government into Arts in Education in the Schools of Wales. Available at:

http://gov.wales/docs/dcells/publications/130920-arts-in-education-en.pdf Date Accessed $10 / 11 / 2015$

Stottman, M. J. 2010. Archaeologists as Activists: Can Archaeologists Change the World? Tuscaloosa: University of Alabama Press

Tully, G. 2007. Community archaeology: general methods and standards of practice. Public Archaeology 6(3), 155-187

Vacca, J. S. 2004. Educated Prisoners Are Less Likely to Return to Prison. Journal of Correctional Education, 55(4), 297-305. 
Wales Reducing Reoffending Strategy 2014 - 2016. Welsh Government. https://www.gov.uk/government/uploads/system/uploads/attachment data/file/453579/Wa les-Reducing-Reoffending-Strategy-e .pdf Accessed 10/11/2015

Warner, K. 2002. Widening and Deepening the Education We Offer Those in Prison: Reflections from Irish and European Experience. Journal of Correctional Education, 53(1), 32-37.

Welsh Archaeological Trusts. n.d. Archwilio. The Historic Environment Records of the Welsh Archaeological Trusts. (C) Copyright Glamorgan-Gwent Archaeological Trust 2010 http://www.archwilio.org.uk Accessed 16/11/2015

Welsh Government, 2012 Tackling Poverty Action Plan 2012-16 Welsh Government Report 14688. Available at:

http://gov.wales/docs/dsilg/publications/socialjustice/120625tackpovplanen.pdf Accessed $10 / 11 / 2015$

Welsh Government, 2013a. Changing Cultures initiative aims to change lives. 7/2/2013. Available at: http://gov.wales/newsroom/cultureandsport/2013/130207changingcultures/\%3bjsessionid= BF997E76FA3294778B4AFF7E188893BF?lang=en (C) Crown copyright 2015. Accessed $10 / 11 / 2015$

Welsh Government, 2013b. Cadw Community Archaeology Framework. Welsh Government Report 19034. Available at http://cadw.gov.wales/docs/cadw/publications/Cadw\%20Community\%20Archaeology\%20Fr amework EN.pdf (C) Crown copyright 2015. Accessed 10/11/2015

Welsh Government, 2013c. Historic Environment Strategy for Wales. May 2013 Avaialble at: http://cadw.gov.wales/docs/cadw/publications/Hist Env Strat Wales John Griffiths EN.pdf (C) Crown copyright 2015. Accessed 10/11/2015

Welsh Government, 2014a. Communities First. (C) Crown copyright 2015. http://gov.wales/topics/people-and-communities/communities/communitiesfirst/?lang=en Accessed 15/11/2015.

Welsh Government, 2014b. Culture and Poverty: Harnessing the power of the arts, culture and heritage to promote social justice in Wales. A report with recommendations by Baroness Kay Andrews OBE for the Welsh Government (March 2014)

Welsh Government, 2015. Welsh Index of Multiple Deprivation. Available at: http://gov.wales/statistics-and-research/welsh-index-multiple-deprivation/?lang=en. Accessed 10/02/2016.

Wennberg, B. K. 2011 Combating cultural heritage crime within the Norwegian police: education and higher competence. In A. Chabiera (ed) Stop Heritage Crime. Good Practice and Reccomnedations. Warsaw: National Heritage Board of Poland, 111-116. Available at: http://www.interpol.int/Media/Files/Crime-areas/Works-of-art/Stop-heritage-crime Accessed $10 / 11 / 2015$

Wennberg, B. K. 2014. Understanding Attitudes - Heritage Crime in Norway. In, L. Grove and S. Thomas (eds.) Heritage Crime. Progress, Prospects and Prevention. Basingstoke: Palgrave Macmillan, 149-168. 
Wheeldon, J. P. and Faubert, J. 2009. Framing Experience: Concept Maps, Mind Maps, and Data Collection in Qualitative Research. International Journal of Qualitative Methods 8(3), 69-83.

Wheeler, R. E. M. and Wheeler, T. V. 1928. The Roman Amphitheatre at Caerleon, Monmouthshire. Archaeologia 78, 111-218.

Wilson, D., and Reuss, A. (eds.) 2000. Prison(Er) Education: Stories of Change and Transformation. Winchester: Waterside Press.

Zimmerman, L. J., Singleton, C., \& Welch, J. 2010. Activism and creating a translational archaeology of homelessness. World Archaeology, 42(3), 443-454.

\section{Notes}

${ }^{1}$ Examples include, but are not limited to the volunteer opportunities on excavations undertaken by the universities of Bangor, Cardiff, Chester, Lampeter. Liverpool, Manchester, Manchester Metropolitan University and University College London as well as more explicit outreach, engagement and community archaeology projects.

2 Including the Historic Environment Strategy for Wales (Welsh Government 2013c).

${ }^{3}$ More on this will be discussed below under impact.

${ }^{4}$ The training kitchen is deemed high risk because of the accessibility of knifes, ovens and particular ingredients.

${ }^{5}$ Priory Field (and therefore the objects), were owned by Cadw and ownership had not yet been transferred to the NRLM. 
MORTARIA

HMP/YOI Parc

Lesson Plan

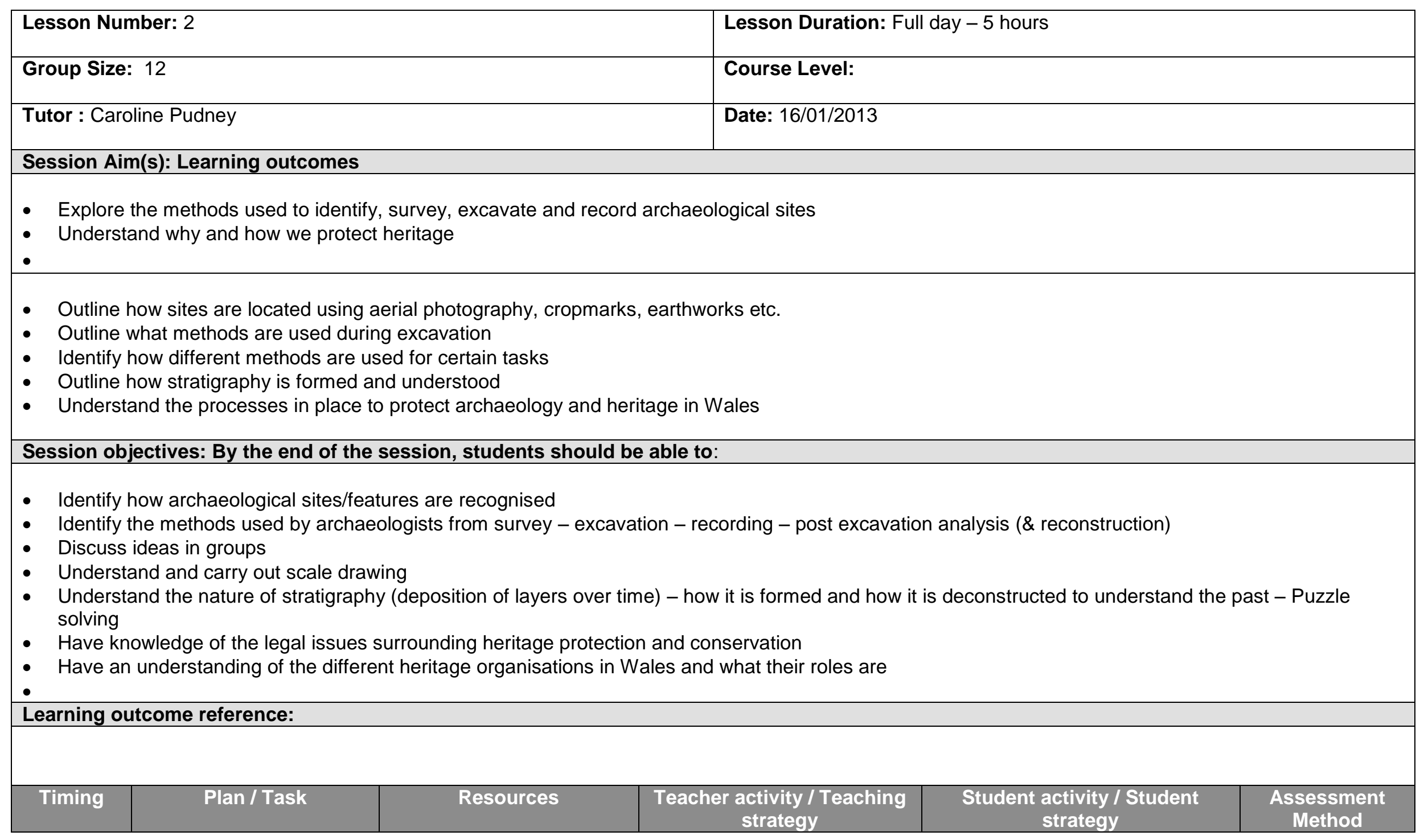




\begin{tabular}{|c|c|c|c|c|c|}
\hline 30 mins & Re-cap - Homework & & $\begin{array}{l}\text { - Lead discussion on what } \\
\text { we learnt last week } \\
\text { - Introduce comprehension } \\
\text { task based on homework } \\
\text { reading }\end{array}$ & $\begin{array}{l}\text { Discuss what they learnt last } \\
\text { week } \\
\text { - Undertake a comprehension } \\
\text { exercise on a piece of } \\
\text { reading }\end{array}$ & $\begin{array}{l}\text { Verbal Q\&A } \\
\text { Written task }\end{array}$ \\
\hline 30 mins & How do we identify sites? & $\begin{array}{l}\text { Whiteboard } \\
\text { W/B Markers } \\
\text { Basic Stationary } \\
\text { Images of earthworks, } \\
\text { aerial photography, maps } \\
\text { etc. }\end{array}$ & $\begin{array}{l}\text { - Lead activity and explain } \\
\text { what we look for and how } \\
\text { features appear in certain } \\
\text { ways. } \\
\text { - Explain the task - run } \\
\text { through an example } \\
\text { image } \\
\text { - Provide support and } \\
\text { assistance during task }\end{array}$ & $\begin{array}{l}\text { - Listen to information } \\
\text { In pairs, apply information to } \\
\text { an image of an } \\
\text { archaeological site. What } \\
\text { can they see and how do } \\
\text { they think it came to look like } \\
\text { this. } \\
\text { Present their image to the } \\
\text { class }\end{array}$ & Verbal Q\&A \\
\hline 30 mins & $\begin{array}{l}\text { Tutorial - Archaeological } \\
\text { Methods }\end{array}$ & $\begin{array}{l}\text { Whiteboard } \\
\text { Powerpoint }\end{array}$ & $\begin{array}{l}\text { - Present ppoint on the } \\
\text { different methods used } \\
\text { by archaeologists when } \\
\text { undertaking fieldwork }\end{array}$ & $\begin{array}{l}\text { - } \quad \text { Listen and observe } \\
\text { - } \quad \text { Ask questions / engage in } \\
\text { discussion where appropriate }\end{array}$ & $\begin{array}{l}\text { Tutor } \\
\text { observation }\end{array}$ \\
\hline
\end{tabular}

\section{Minute Break}

\begin{tabular}{|l|l|l|l|l} 
Timing & Plan / Task & Resources & Teacher activity / Teaching & Student activity / Student \\
strategy & Assessment \\
Method
\end{tabular}




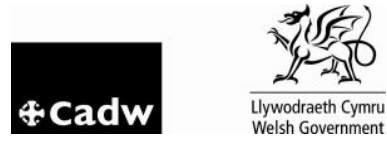

\begin{tabular}{|c|c|c|c|c|c|}
\hline 60 mins & $\begin{array}{l}\text { DVD - Time Team } \\
\text { Episode }\end{array}$ & $\begin{array}{l}\text { DVD player } \\
\text { Screen }\end{array}$ & $\begin{array}{l}\text { Explain what students } \\
\text { need to look for during } \\
\text { the video. } \\
\text { prior to start - run through } \\
\text { questions being set and } \\
\text { ensure pupils understand } \\
\text { them } \\
\text { - Run through the answers } \\
\text { at the end }\end{array}$ & $\begin{array}{l}\text { Watch video and list } \\
\text { archaeological methods } \\
\text { being used - answer } \\
\text { questions on worksheet } \\
\text { Consider why certain } \\
\text { methods were being used } \\
\text { and others were not }\end{array}$ & $\begin{array}{l}\text { Written Task } \\
\text { Verbal Q\&A }\end{array}$ \\
\hline 10 mins & Question Time & & $\begin{array}{l}\text { - Answer Quick-fire } \\
\text { questions }\end{array}$ & $\begin{array}{l}\text { - Ask the tutor quick-fire } \\
\text { questions }\end{array}$ & Verbal Q\&A \\
\hline
\end{tabular}

\section{LUNCH}

\begin{tabular}{|c|c|c|c|c|c|}
\hline Timing & Plan / Task & Resources & $\begin{array}{c}\text { Teacher activity / Teaching } \\
\text { strategy }\end{array}$ & $\begin{array}{c}\text { Student activity / Student } \\
\text { strategy }\end{array}$ & $\begin{array}{l}\text { Assessment } \\
\text { Method }\end{array}$ \\
\hline 60 mins & Stratigraphy & $\begin{array}{l}\text { Large life-size images of } \\
\text { archaeological section and } \\
\text { wall elevation } \\
\text { Projector } \\
\text { Computer } \\
\text { Squared paper } \\
\text { Rulers } \\
\text { Tape measures } \\
\text { Tracing paper } \\
\text { Pencils } \\
\text { Erasers }\end{array}$ & $\begin{array}{l}\text { - Explain stratigraphy, and } \\
\text { recording practices } \\
\text { (section drawing) } \\
\text { - Explain working to scale } \\
\text { - Run through method of } \\
\text { scale drawing in relation } \\
\text { to recording sections }\end{array}$ & 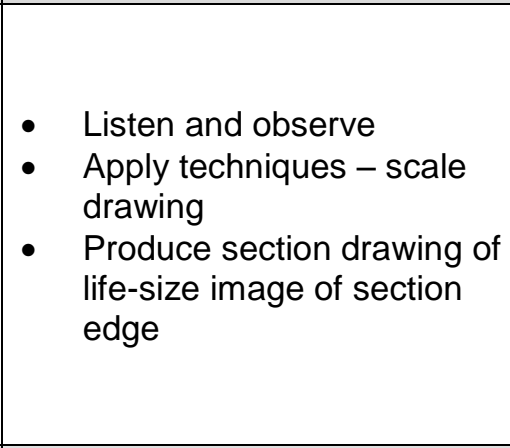 & $\begin{array}{l}\text { Drawn/written } \\
\text { task } \\
\text { Tutor } \\
\text { observation }\end{array}$ \\
\hline
\end{tabular}




\section{0 minute Break}

\begin{tabular}{|c|c|c|c|c|c|}
\hline Timing & Plan / Task & Resources & $\begin{array}{c}\text { Teacher activity / Teaching } \\
\text { strategy }\end{array}$ & $\begin{array}{c}\text { Student activity / Student } \\
\text { strategy }\end{array}$ & $\begin{array}{l}\text { Assessment } \\
\text { Method }\end{array}$ \\
\hline 60 mins & $\begin{array}{l}\text { Conservation and } \\
\text { Protection - Tutorial }\end{array}$ & $\begin{array}{l}\text { Whiteboard } \\
\text { Powerpoint } \\
\text { Basic Stationary }\end{array}$ & $\begin{array}{l}\text { Explain process in place } \\
\text { to protect archaeology } \\
\text { and heritage } \\
\text { Outline the various } \\
\text { heritage organisations in } \\
\text { Wales and their roles and } \\
\text { responsibilities } \\
\text { - Explain activity }\end{array}$ & $\begin{array}{l}\text { - Listening and Observation } \\
\text { - Comprehension - answer } \\
\text { worksheet based on tutorial }\end{array}$ & $\begin{array}{l}\text { Verbal Q\&A } \\
\text { Written task }\end{array}$ \\
\hline \multicolumn{6}{|c|}{ END } \\
\hline
\end{tabular}



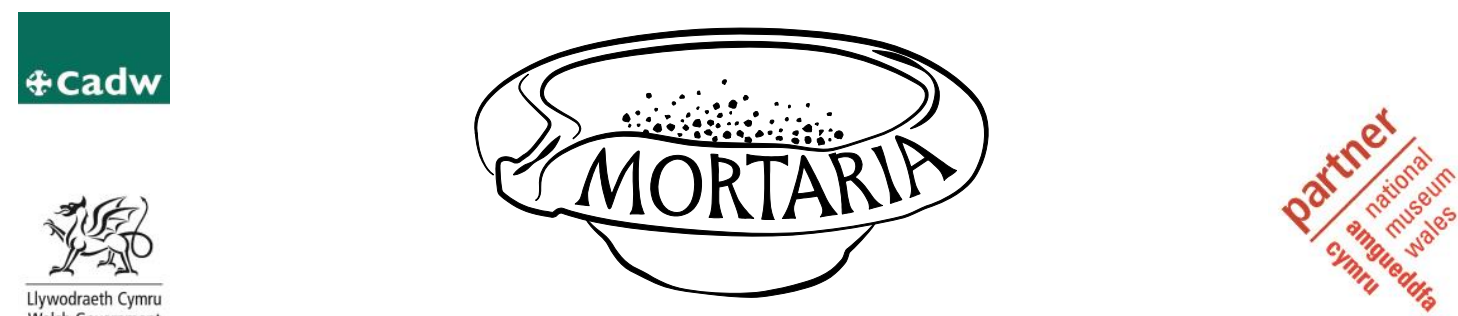

\section{Student Information Booklet}

2014

Thursdays: $08.15-12.00$

$14.15-17.15$

The MORTARIA Workshops that you are entering into will introduce you to the archaeology of Wales. Archaeology can offer a fantastic opportunity for you to gain practical skills, valuable hands-on work experience and have the chance to work as part of a team, alongside experts in the field.

On successful completion of this course participants will gain a either a Level 1 Agored Cymru Award or a Level 1 Certificate in 'Window on Wales'.

Your course tutor will be Caroline Pudney, Cadw's community archaeologist. Guest speakers will join sessions throughout the course to share their own expertise and provide an opportunity for participants to gain a fuller experience of archaeology and heritage in Wales.

\section{What is the MORTARIA Course?}

1.1 In its basic form, the course is a series of workshops in which professional archaeologists from Cadw (Welsh Government's Historic Environment Service) and the National Museum Wales provide individuals with experience of archaeology and help to develop both subject specific and generic skills and behaviours.

All participants in the workshops will receive basic training in archaeological postexcavation methods including artefact processing and recording (drawn and written), identification, analysis and interpretation. In addition to this, participants will learn about past people through the material remains they have left behind.

1.2 The general outcomes that the MORTARIA project (and archaeology in general) can offer range from skills in literacy, numeracy and ICT to observation, team working, communication, lateral thinking and initiative. 
Generic:

- Demonstrate awareness of relevant archaeological concepts and methods in nonarchaeological situations.

- Perform assigned tasks as part of a team, participating in discussion.

- Bring together information and materials from different sources.

- Identify problems and questions.

- Undertake the analysis of factual information.

- Recognise weaknesses in the arguments of others.

- Produce a synthesis of the state of knowledge on a particular subject or topic.

- With guidance, undertake tasks independently.

- Self-motivate

- Manage his time effectively.

- Reflect on his own progress.

- Express himself both orally and in writing.

- Present knowledge or an argument in a way which is comprehensible to others.

- Use IT to select and present information.

- Make oral presentations utilising visual aids.

- Demonstrate an ability to listen and comprehend when presented with new ideas or information.

- Demonstrate visual skills in recognising and describing material remains.

Subject specific:

- Demonstrate knowledge of British history and archaeology.

- Understand the principles and methods by which archaeological data are collected, recorded, analysed and interpreted.

- Demonstrate practical experience of the recording of primary archaeological data.

- Observe and describe different classes of primary archaeological data and objectively record their characteristics.

- Appropriately draw upon scholarly, theoretical and scientific principles and concepts and apply to archaeological problems.

- Select and apply appropriate practical and numerical techniques to process archaeological data, recognising the potential and limitations of such techniques.

- Reflect critically upon archaeological data and demonstrate comprehension of the problematic and varied nature of archaeological evidence in artefact-based studies.

- Gather and present archaeological evidence from primary and secondary sources.

- Discover and recognise the archaeological significance of material remains and how they can inform us about the past.

- Demonstrate awareness of the social, cultural and political context of archaeological interpretation.

\section{Course Outline}

\section{Workshop 1}

The introductory session is a chance to meet the tutor and find out about what's in store. 
What is Archaeology? You will be introduced to concepts including chronology, archaeological artefacts and how archaeologists begin to identity and understand objects that may have been buried for thousands of years.

\section{Workshop 2}

How we know what they knew

Session 2 will provide an introduction to archaeological methods, how and why we preserve historic remains in Wales and will also ask participants to explore our impact on the world today. Participants will know how archaeologists identify sites and investigate them and will be able to decide which techniques are most appropriate in certain situations. The workshop will also give participants skills in archaeological recording and a good understanding of the measures in place for heritage protection in Wales and the UK.

\section{Workshop 3}

Early Prehistory

This session will cover the earliest periods in human history and in doing so will incorporate climate change, human development, social change and the earliest technological developments.

\section{Workshop 4}

The Bronze Age

Workshop 4 will introduce participants to the Bronze Age in Wales through the artefacts left behind. This will incorporate the revolutionary discovery and use of copper, how societies changed and traded and the iconic burial practices with their associated religious beliefs.

\section{Workshop 5}

The Iron Age

This workshop unravels the Celtic history of Wales through focusing on a series of case studies from Iron Age Wales. Iron Age technology, society and politics will be addressed through settlement evidence and material remains. This session will also set the scene for what comes next...

\section{Workshop 6}

\section{The Romans}

The Roman Conquest of Wales had a considerable and lasting impact upon the people living there. This workshop will outline the major changes which were brought through Roman rule and give participants a taste of what life would have been like for those living in and around the Roman fortress at Caerleon, near Newport.

\section{Workshop 7}

Re-constructing ancient art

Create a Roman fresco using traditional methods 


\section{Workshop 8}

Migrations and Invasions

This session will give participants a taste of life in Wales after the end of Roman rule and before the Norman Conquest of 1066. Traditionally referred to as the Dark Ages, this period is full of invasions, migrations and was a time of myth and legend and when the Christian religion of Wales began to be formed.

\section{Workshop 9}

Medieval Mysteries

Workshop 9 will transport participants back to the age of castles in Wales - what were these structures like for the people that lived in and around them? This session will look at the architecture of castles as well as the objects used within them in the daily lives of their inhabitants. The relationship between the castles and the surrounding towns and villages will also be explored.

\section{Workshop 10}

Historic Dining

Participants will be cooking and eating a feast fit for a Welsh Prince (or Roman emperor).

\section{Workshop 11}

Our Industrial Past

Workshop 11 focuses on Wales' industrial past through the structural remains. The session will explore the types of industry, the impact upon local societies and decline of these industries. This decline has led to the abandonment and destruction of many buildings associated with this period in history. The historic importance of these sites however, is now being realised and their protection is becoming more common - one of these sites is in fact seen as being internationally important and is preserved as a World Heritage Site this site will form the main focus of the session.

\section{Workshop 12}

The Archaeology of War

In this workshop participants will explore the physical remains of the First and Second World Wards as well as the Cold War. This will include exploring the physical and structural remains and the impact of war upon settlements in Wales. Some objects of conflict will be studied and the affects on the lives of the people in Wales during these periods of conflict will also be considered.

\section{Workshop 13}

Heritage in Today's World

This final workshop presents a time to reflect on the course and explore the importance, relevance and management of heritage in Wales today. Participants will also prepare materials for the graduation ceremony and exhibition. 